\title{
THE IMPORTANCE OF ENTREPRENEURIAL LEARNING ON THE EXAMPLE OF THE SOUTH EAST EUROPEAN CENTER FOR ENTREPRENEURIAL LEARNING IN CROATIA
}

\author{
Sanja Maleković, Sanja Tišma, Ivana Keser* \\ IRMO, \\ 2 Farkaša-Vukotinovića St., Zagreb, Croatia
}

\begin{abstract}
:
The paper focuses on the experience in development of entrepreneurial learning (EL) policy in South and East Europe (SEE), as a result of activities implemented by the South East European Center for Entrepreneurial Learning (SEECEL) in Croatia. It aims to explore whether the EL concept, as promoted and developed by SEECEL, can also contribute to development of an entrepreneurial mindset and behaviour, creative thinking, as well as enhancing the development of individual's entrepreneurial characteristics regardless of their ambition to start/conduct some business. The authors also seek to explore the relevance of the exchange of experience, effective partnership and cooperation of all involved education and other institutions and actors engaged in policy support for further development of the EL approach in SEE. The authors address different perspectives and understandings of the EL concept, point out to the existence of different schools of thought on EL, and consider the interaction between learning and entrepreneurship, which asks for novel and rigorous theorizing.
\end{abstract}

\section{Key words:}

education and training, entrepreneurial learning concept, life-long learning.

\section{INTRODUCTION}

Besides its serious adverse effects, the ongoing economic crisis, which emerged in 2008, has also severely affected the growth potential and youth employment, and has resulted in an increasing interest in education and training issues aimed at triggering growth and jobs.

The search for possible solutions has also fostered the promotion of entrepreneurial education as a means of satisfying competitiveness and social (employment) agenda. Even though reference is basically made to entrepreneurial education in the current academic and policy literature, our attention shall be placed on the two basic principles of entrepreneurial learning (EL). According to Gribben (2013), the first principle stems from the notion that all individuals should be encouraged to be more entrepreneurial, regradless of their ambition to start some business. The rationale is that entrepreneurial employees will be innovative and adaptable in the fast-changing economies, and should become more efficient and effective resource managers. The second notion is that EL includes all 
forms of education and training - formal, non-formal (not covered through the standard education curricula), as well as informal and incidental learning, relevant from the point of view of contributing to a more entrepreneurial mindset and behaviour.

The European Commission's (EC) policy considers EL from a wider perspective, based on the considerations of entrepreneurship as a key competence, with education and training having a prominent role in cultivating the entrepreneurial mindset of young people, their intentions toward entrepreneurship, employability, as well as their role in society and the economy (EC, 2012). The need to embed creativity, innovation and entrepreneurship into education to unleash entrepreneurial and innovative capabilities are also highlighted in the European Union's (EU) 2020 strategy. Furthermore, the European reference framework, "Entrepreneurship and Sense of initiative" is highlighted as one of the key eight life-long learning competencies that citizens need to possess for their personal fulfillment, social inclusion, active citizenship and employability in the knowledge-based society (EC, 2012).

As Politis (2005) and Rae (2000) remark, EL is not solely conditioned by a commercial or profit objective. EL equally contributes to more entrepreneurial employees, which is relevant for the overall business performance. Pursuant to the renewed Lisbon Strategy, the promotion of entrepreneurial culture is of vital importance for generating jobs and economic growth in Europe.

As regards South East Europe (SEE), efforts are currently underway at the national level to integrate EL as the key element of promoting sustainable economic growth and fostering competitiveness. Following these national efforts, the South East European Centre for Entrepreneurial Learning (SEECEL) was established as a regional institution in Croatia in 2009 with the aim to promote inclusion of entrepreneurial learning in eight countries of SEE (Albania, Bosnia and Herzegovina, Croatia, Kosovo, Macedonia, Montenegro, Serbia and Turkey). The Center primarily functions as a policy facilitator for its member countries, thus ensuring high-quality outputs through its regional activities in policy guidance, advice and assistance to key stakeholders in the field of entrepreneurial learning (Van't Rood \& Maleković, 2012).

During the research period, the following four pillars of SEECEL came to the forefront:

- Development of the entrepreneurship key competence (ISCED 2 level)

- Promotion of entrepreneurship/entrepreneurial learning at the third level education (ISCED 5/6 level) within non-business disciplines

- Enterprise-driven training needs analysis

- Dissemination and promotion of good policy and good practice.

SEECEL's main activities relate to the promotion and development of entrepreneurial culture and entrepreneurial learning as a key competence in both formal and informal education in SEE with the aim of strengthening the competitiveness of small and medium-sized enterprises in line with the previously mentioned EC policy. SEECEL demonstrates how these countries are cooperating and initiating joint activities with the aim of sharing ideas and experience, while creating added value and establishing the "Life-Long Entrepreneurial Learning System" in the region (Van't Rood \& Maleković, 2012).

\section{THE AIM OF RESEARCH}

On the basis of the scholarly inquiry, review of the current academic literature on EL and evaluation results of the first three years of SEECEL's programme, the principal aim of this paper is to explore whether the EL concept, as promoted and developed through SEECEL's programme in SEE, can contribute to development of an entrepreneurial mindset and behaviour, problem solving, creative thinking, identifying opportunities, and enhancing the development of an individual's entrepreneurial character regardless of their ambition to start a 
business. It also aims to measure the relevance of exchange of experiences, effective partnership and cooperation of all involved institutions and actors engaged in policy support for achieving effectiveness as well as to examine the impact of initiatives aiming at further strengthening the EL approach in SEE.

The main point of our examination is not the creation of new successful entrepreneurs, but EL's contribution to the improvement of entrepreneurial mindset of young people, assisting them in becoming more creative and self-confident in whatever they undertake, along with facilitating them in finding attractive jobs, and contributing to their improved role in society and the economy.

\section{METHODOLOGY AND APPROACH}

In order to fulfill the main objectives of this paper, our research builds on the previous scholarly research findings on the EL concept. In addition, the empirical part of the research draws on the results of the evaluation process of SEECEL programme, based on the evaluation criteria of relevance, effectiveness, efficiency, impact and sustainability. The evaluation process, which gave us a profound insight into the problems and needs related to the introduction of the EL concept in the SEE region, was also focused on recommending changes of the strategy with the aim to further strengthen the SEECEL's concept and approach, thus contributing to future development of the EL concept in SEE.

During the research period, SEECEL's programme covered 32 schools (ISCED level 1), 64 schools (ISCED level 2), 32 general education high schools, 16 high schools (ISCED LEVEL 5/6) and 8 institutions in charge of the teaching staff life-long learning. A multiple case study was utilized herein as the major research strategy. Furthermore, we used the principle of multiple data sources (triangulation), with data being collected through a number of research sources: documents, interviews and focus groups. In-depth interviews were chosen as the method of data collection in all eight countries. Interviews were held with 16 stakeholders, including mainly those from the Ministries of Education and Economy (four from Serbia, one from Bosnia and Herzegovina, two from Turkey, two from Albania, two from Macedonia, three from Croatia, one from the European Commission - DG Enterprise and one from the European Training Foundation). Interviews were also held with 8 teachers/professors (teachers from elementary schools in Montenegro and Bosnia and Herzegovina, as well as university professors from Bosnia and Herzegovina and Croatia). Furthermore, interviews were held with SEECEL staff. Three focus groups were held, one in Montenegro (including the main stakeholders as well as teachers from 4 schools and professors from 2 faculties), while the remaining two were held with teachers and principals in elementary schools in Serbia and Bosnia and Herzegovina.

When it comes to the tools utilized, a thorough literature survey was carried out, along with indepth interviews, focus groups, interviews, discussions and debates with school managment, teachers and pupils in schools participating in the project. Three types of specific questionnaires were developed for stakeholders and pilot institutions involved in the implementation of SEECEL's programme. Responses were provided by 14 respondent questionnaires, including the main stakeholders and pilot schools and faculties in all SEECEL member countries. Our conslusions and recommendations were based on the profound analysis of available research findings and documentation, the analysis of the interview outcomes, as well as the questionnaire responses, which mutually complement the initial research findings.

Among the interviewed entities were the stakeholders from the countries participating in the project, business associations, pilot schools and faculties, professors, teachers, students, pupils and others. Stakeholders in Bosnia and Herzegovina, Serbia, Croatia, and Montenegro were visited and interviewed in their countries. The applied meth- 
odology was particularly participatory at all stages. It was result-oriented and focused primarily on the issue of achieving ownership and committment related to project results.

\section{ENTREPRENEURIAL LEARNING CONCEPT}

The EL concept has attracted considerable attention of part of the academic community over the past decade. Despite significant development in the research domain, a number of authors deem that the understanding and knowledge of interaction between learning and entrepreneurship is still limited, asking for novel and rigorous theorizing in order to develop a more complete and accurate understanding of how knowledge evolves (Holcomb et al., 2009; Corbett, 2005), with Cope (2005) the comments that a better grasp of EL is of crucial importance, as learning is the prerequisite for further development and growth of entrepreneurs. Even though recent scholarly research has concentrated more on EL in higher education, the common view is that EL concerns the development of entrepreneurial capabilities through life and work (Kakkonen, 2010; Rae \& Carswell, 2001; Gibb, 2005). Entrepreneurship and entrepreneurial activities are often identified with economic activities. However, a person can be entrepreneurial (creative, innovative, prone to team work, accountable, independent), without being involved in entrepreneurial activities. The authors present different ways of doing things (Tkalec, 2011).

Different ways of understanding and EL perspectives have resulted in numerous definitions. Rae (2006) understands EL as an integral part of the entrepreneurial process in which human and social aspects are as important as the economic ones. The same author also defines it as learning to recognize and act on opportunities, and interacting socially to initiate, organize and manage business ventures. His observation is that this process had the double connotation of both learning to behave in, as well as learning through entrepreneurial ways. Furthermore, he observes that learning should be relational, authentic, relevant, useful and productively shared (Rae, 2009). In his further work, Rae purports EL, among other, as: learning and acting in an innovative and opportunistic way; applied creativity, recognising, creating and acting on opportunities; social interactions for self and social learning; creating multiple forms of values; and transformative, social, imaginal, emotional and experiential learning (Rae, 2011).

Other authors refer to EL as the process by which people acquire, assimilate and organize newly formed knowledge with the pre-existing structures, and refers to the ways in which learning affects entrepreneurial action (i.e., Cope, 2005; Corbett, 2005; Harrison \& Leitch, 2005; Minniti \& Bygrave, 2001). Gibb and Sogunro argue that traditional teaching methods, lectures and examinations do not activate entrepreneurship (Gibb, 2002; Sogunro, 2004). Apparently, along with knowledge, traditional teaching methods ask for new ways of thinking, new skills and new modes of behaviour, as well as entrepreneurial approaches. This requires students' active participation in class, co-learning between teachers and students, with the student having ownership of her or his learning and the teacher supporting them and facilitating the overall process (Heinonen \& Poikkijoki, 2006; Gibb, 2002; Fiet, 2001). A further immanent characteristic of the EL teaching approach is learning through experience, with Kolb (1984, p. 41) defining it as "the process whereby knowledge is created through transformation of experience".

The presented observations indicate the existence of different schools of thought on EL (Kakkonen, 2010). Such observations apparently trigger scholarly inquiry and additionally emphasise the need for further, intensive academic research on the EL concept. Whilst we are witnessing academic debates on the main contributions of the EL approach and learning through experience, Pittaway et al. (2012) refer to some of the common features, from opportunities being created for individuals to learn from mistakes and grow personally, experiences allowing social learning as well as individual learning (McLaughlin \& Thorpe, 1993; Mumford, 
1994), to reflection following experience which occurs when learning happens (Burgoyne \& Hodgson, 1983; Daudelin, 1996).

Such education is also a means of increasing social inclusion, and as referred to in the EC (2012) Report, it can be a gateway for greater integration of the framework for the key life-long learning competencies. In this regard, we are referring to a learner-centred approach or participatory approach. Simultaneously, the approach also contributes to more efficient and effective teaching, making it more enjoyable for both learners and teachers. It requires from the teacher to develop students' abilities in order to reflect on their own experiences, putting them in a wider context, (Gibb, 2002). It is a quite different approach demanding more effective cooperation and interaction between the learner and the teacher. Moreover, Heinnonen and Poikkijoki (2006) remark that if you are able to get the students moving, you are likely to gain more access to their thoughts as well. Intuitive and innovative thinking is thus activated as well as experimenting with creativity and individuality (Carayannis et al., 2003).

Based on the previously mentioned, introduction of EL concept at all levels can, in a longer term perspective, evidently contribute to higher growth and employment rates, more effective social security systems. It can also represent the basis for sustainable economic growth (Tafra, 2011). On the basis of Tafra's (2011) reference to the main goals on the example of the Croatian EL strategy, it is reasonable to expect that EL simultaneously contributes to employability, the start-up of new small and medium-sized enterprises, higher rates of young people starting their business, higher rates of women's entrepreneurship, creativity, innovation and competitiveness.

In line with its entrepreneurship drive and the aforementioned, the EC's aim is to encourage neighbouring countries undergoing significant institutional and policy reforms to adopt more strategic approaches to EL in the framework of their education and training systems (EC, 2006). EC perceives a major challenge in ensuring full engagement and ownership of the EL agenda from the part of all stakeholders, particularly education authorities, supported through their leadership in the process of reform implementation. Since the EL concept is relatively new, a number of institutions, with the European Training Foundation being in the forefront, are pointing to the key role of teachers and the needs and benefits of sharing best practices among the involved institutions and relevant actors in different countries. As Gribben (2013) observes, cooperation between strategic partners from the public and private sectors, including the civil society and interest groups, is of vital importance and adds value to an evolving policy.

These observations indicate the relevance of introducing the EL concept in SEE countries, which are considerably lagging behind in introducing such innovative approaches in the education system. Projects encompassing a wide array of institutions, pupils and students, as was the case with SEECEL's programme, can trigger what Baker et al. (2005) refer to as "experiential learning, where learners construct new knowledge and/or meaning through collective experiences". Experience with project based approaches is common and is used proactively to encourage learning (Raelin, 1997).

SEECEL's project, covering eight SEE countries, being itself an example of best practice, is amongst those which enable learning from experience based on the concrete achievements and successful results in all of the included pilot institutions in the SEECEL member countries (schools, universities), as well as learning based on the mainstreaming of the EL concept in education and entrepreneurship policies of the member states. In essence, SEECEL's objectives and observed achievements are very complementary to Rae's observations as to why EL actually matters. $\mathrm{He}$ also advocated EL's contribution to creative thinking (stimulates vision, ambition and action), development of students' confidence to act 
in uncertainty; its contribution to enabling lifelong learning - learning how to survive and grow; and finally, its contribution to finding and enacting opportunities which create value from latent resources (Rae, 2011).

\section{FINDINGS}

\section{SEECEL Programme Contribution to Development of Entrepreneurial Learning Concept in South East Europe}

The findings presented in this chapter follow the main evaluation criteria. The review of literature and response obtained from the stakeholders in the SEECEL member countries confirmed that the strengthened cooperation between policymakers and pilot schools in the implementation of entrepreneurial learning is from their perspective among the most meaningful achievements so far.

The results of this project are multi-fold. The development of models and methodologies triggering entrepreneurial development in the involved partner institutions are some of the most relevant benefits. Stakeholders from Albania pointed to additional contributions in development of education systems, aligned with the EC educational policy. In Macedonia, EL became a government priority as a result of the project, with possibilities for including EL as a subject in primary schools. On the other hand, involved institutions, as was the case with the Chamber of Commerce in Serbia, whose main value in the project was development of new services and more developed cooperation with other partners in the SEE region. As regards Montenegro, Bosnia and Herzegovina and Croatia, teachers indicated the benefits of the new working experience for both students and teachers, and particularly the new visible entrepreneurial atmosphere developed as a result of implementing entrepreneurial ideas.

Furthermore, involved schools and faculties observed that they were able to create additional value in their work by using the Community of Practice (CoP) which facilitated the sharing of knowledge and expertise throughout the SEE region, enabling simultaneously further cooperation on other related projects of mutual interest. Along with other instruments and documentation developed by SEECEL, the faculties in Montenegro and Bosnia and Herzegovina consider it a useful way of being informed and learning on the basis of implemented activities and results of other pilot institutions, as well as a means of learning from the experience of other partners involved in the project.

Along with CoP, close cooperation among partners was mentioned as the factor which contributed to the effectiveness of the implemented project. Furthermore, the respondents in pilot institutions indicated that the programme enabled them to animate pupils/students, to include them into project's activities, empowering them to make decisions individually and within a group, as well as to develop entrepreneurial ideas. The responses obtained through questionnaires confirmed that the project triggered a creative and enthusiastic response from part of pupils and teachers, with the latter being visibly motivated to develop ideas for new activities. Such an approach in the implementation of project's activities resulted in strengthened professional and personal relationships among teachers participating in the project. Additional value is seen in schools having developed cooperation with local entrepreneurs. On the whole, pupils and students demonstrated a more enthusiastic and by all means, different perception and attitude towards learning.

The evaluation results have confirmed that the effectiveness of promoted measures and initiatives will be strengthened once teachers, along with related authorities, are more involved in the planning, design as well as direct implementation of strategies and action plans being developed. This will simultaneously be reflected in the sustainability of results and long term impact of projects and activities targeting EL development. Gribben (2013) furthermore elaborates on the possibilities for teachers evolving into a recognised advocacy group, thus presenting an important policy force both at national and EU level. 
From the achieved impact point of view, SEECEL's programme has undoubtedly contributed to improvements related to fostering EL in SEE. Observations made during interviews indicate that SEECEL's activities have triggered positive changes in national developments and achievements in the EL segment. For example, in Macedonia, Montenegro and Serbia, national partnerships for EL were developed, while in Albania, Croatia, Kosovo and Montenegro, national strategies on EL development were elaborated. The impacts could also be observed in raised beneficiary awareness of the usefulness of project results, as well as in the growing ownership of the key stakeholders and beneficiaries related to the achieved results and their sustainability.

The respondents themselves see impact in SEECEL contributing to development of a life-long learning culture from an early stage. They perceive it as a key condition for building a knowledge-based society and recognizing its role in promoting participation of all country stakeholders in this process. Furthermore, the created network of key institutions and firms on the local level, including primary schools, which jointly implemented different initiatives, was also a relevant contribution. In Zenica, the faculty indicated the importance of developing the entrepreneurial spirit in elementary schools, even though this is a long-term process, whose results will be visible over a long-term period.

As to the most relevant benefits of the project during the three-year period, the project partners pointed to the established cooperation among the institutions on the central government level, aiming at developing EL, design of teacher training standards and promotion of the entrepreneurial teacher, entrepreneurial student and entrepreneurial schools. Further achievements are also visible in terms of development of self-initiatives in the pilot schools and universities, as well as in promotion of the learner-centred approach, relevant from the point of view of introducing significant changes in several countries of the region in which the traditional and conservative teacher-centred approach prevails (Van’t Rood \& Maleković, 2012).
SEECEL's programme has undoubtedly enabled national stakeholders to strengthen national coordination targeting EL in all SEECEL member states. Along with the aforementioned, it raised the capacity of institutions in SEE to further EL development, coherent in regard to the relevant strategic national as well as EU policy priorities. Based on the received responses, it is confirmed that the SEECEL instrument, along with being recognised by 5 member states and the Eastern Partnership has also been recognized by the EC, countries as well as the broader international community involved in entrepreneurial learning. The above-mentioned confirms the overall impact of SEECEL's programme.

As to the evaluation criteria sustainability and on the basis of the implemented methodological approach, it can be observed that SEECEL actively promotes ownership of lifelong EL development from the part of all key stakeholders in the participating countries with the aim of ensuring sustainability of the results. Based on the knowledge acquired over a few years period, due importance from the part of all stakeholders and pilot institutions is given to possible transferability of activities in other similar institutions in the region. For example, a number of schools involved in the project, including the school Alas in Belgrade, as well as in Grude (Bosnia and Herzegovina), but also faculties (Bijeljina in Bosnia and Herzegovina) confirmed they were eager to support other institutions with similar initiatives. Their willingness to foster knowledge dissemination and replication of successfully implemented activities is a relevant project outcome.

\section{OVERALL ASSESSMENT AND RECOMMENDATIONS}

Based on the scholarly research conducted on the EL concept, review of available policy documentation and evaluation results following the main evaluation criteria, this chapter comprises an overall assessment of SEECEL's programme in SEE 
and provides several key recommendations aiming at sustaining the most relevant achievements and further developing the EL concept in the region.

As regards the effectiveness of SEECEL's programme, it is of pivotal importance for EL to be embedded in the learner-centred/competence based approaches. Currently, such approaches have still not been introduced in the education systems in all of the SEE countries. Teachers/coordinators in the pilot schools in SEE countries are in need of further training. Furthermore, the concurrent evaluation results confirmed the need for bridging the gap between EL theory and classroom practice in pilot institutions. The implementation of EL as a key competence evidently requires a systematic approach and targeted educational institutions as units of change. Implementation is only possible if it encompasses three key elements: curriculum through learning outcomes definition, teacher training and school management for an entrepreneurial environment.

A profound insight into the current circumstances related to ownership and commitment to the EL approach from part of all relevant national institutions in SEE countries allow us to assess that sustainability of the programme's results. However, there are grounds for more effective EL coordination and leadership in most of the countries involved in the project, particularly related to better cooperation and coordination of the Ministries of Education and Economy, as well as the business sector.

The CoP platform - that has led to developed modalities of peer learning, and generated momentum for structured cooperation in the development of LLEL - forms a solid basis for further SEECEL activities in targeting EL development. These achievements have contributed to the SEECEL recognition from the part of national education institutions as a think tank for development of entrepreneurial literacy, as well as recognition from the part of EU member states and Eastern Partnership countries of SEECEL as a reference point for EL.

\section{RECOMMENDATIONS}

The academic inquiry on different perspectives and current challenges related to the EL concept, followed by an in-depth evaluation, allow us to indicate several recommendations for further development of the EL approach in SEE, the first of which adheres to the applied evaluation criteria.

The EL concept needs to be implemented at all levels of education in the region, including VET, secondary education and higher education, as well as teacher training. Karajić, Dabić and Cingula are among those whose research results point to the need of including entrepreneurship as a key competence in curricula at all levels of formal education (Karajić et al., 2012). More emphasis should also be placed on promoting innovation and strengthening cooperation and linkages between the academic community and the private sector, including spin-off companies. Further human resource development in the SEECEL member states is also necessary.

Having in mind the strengthening of the effectiveness and mainstreaming of the EL approach, a suggestion is placed forward to use current initiatives on introducing learner centred/competence based concepts in education systems of the involved countries. The sharing of experience and looking at why things work elsewhere can be very useful. Furthermore, it is suggested that training should be organized at school level for teachers in schools introducing/implementing the EL approach on how to develop EL within the existing curriculum and teaching approach, including content related matters (with more focus on economic issues). More effective cooperation and linkages among government agencies, the private sector and civil society within the member states also deserve due attention. Finally, support needs to be provided to EL development in non-formal adult training.

In order to ensure sustainability of the EL approach, it needs to be included in the second- 
ary education, vocational education and training (VET) and in pre- and in-service teacher education (higher education) in each member country. The capacity of teachers and trainers of trainers also needs to be built. Gribben (2013), also explicitly points out to the need of ensuring all new teachers entering the profession leave teacher training college with a solid basis to be built upon. School principals also need to be trained in providing leadership, at school level, of EL activities, and the system of rewarding pilot school teachers should be introduced. Their motivation is very meaningful. While discussing the international assistance programmes and the reform of the vocational education in the Western Balkans, Bartlett (2013, p. 346) observes that the effective implementation of reforms is likely to depend on the motivation and attitudes of an individual school director, as well as enthusiastic teaching staff members, as value added provided by international assistance itself.

In order to ensure further impact, more emphasis needs to be placed on the methodological and content related matters at all education levels by utilizing current initiatives to introduce competence-based learning as a means for introducing EL. Furthermore, efforts should be made to enable pupils and students to "connect" to "real" entrepreneurs and their lives. The findings related to ensuring long-term impact relate to Rae's observation on the richness and authenticity when accessing the "real lived experience" of entrepreneurs. The possibility of talking to entrepreneurs, learning about their experience, listening to and making sense of their stories can produce a tremendous added value and learning experience (Rae, 2000). Finally, the achievement of relevant impact asks for continuous monitoring and evaluation of the EL policy. A more systemic approach to evaluation, as the key driver of change and improvement, is of strategic importance (for more on needs and benefits of evaluation policies see: Maleković \& Tišma, 2011).

\section{CONCLUDING REMARKS}

The analysis of the current academic and policy literature related to the EL concept, as well as the results of the implemented evaluation allow us to conclude that the EL approach is undoubtedly a relevant factor for equipping young people with the knowledge, skills and attributes necessary not only for those pursuing careers as entrepreneurs. This approach is of pivotal importance for preparing them to be responsible, accountable, proactive, enterprising, creative, motivated and adaptable individuals, those with strong attitude and a sense of initiative and readiness to take risks. The assessment of achievements and interviews with the youth in the pilot institutions engaged in SEECEL's programme demonstrated that the programme contributed to development of an entrepreneurial mindset and behaviour, problem solving and innovative thinking. The approach evidently encouraged a positive response from part of pupils and students who openly expressed their wish towards their further enrolment within the project.

Rather than perceiving EL as bridge-building infrastructure, we should regard it as support infrastructure that needs to be developed over a longer time span, requiring effective coordination, knowledge, consensus, ownership and sustained commitment from the part of education and other authorities in close cooperation with experts, private and civil interest groups at all governmental levels. The engagement of teachers is particularly important and will be more effective if they have full understanding of the concept, understanding that it is a policy affecting sustainable economic growth and employment, particularly for young people. The results of the evaluation lead us to the conclusion that there is still certain potential and scope for their more effective involvement, which will be possible once they are empowered, as well as once the key education stakeholders at the national level demonstrate adequate accountability. It is not possible to achieve ownership without 
empoverment, which is possible once people have acquired life skills of care, responsibility and safety in a comprehensive manner: they understand what to do, the purpose of their task(s), and how to implement their activities (Van't Rood \& Maleković, 2012).

The ownership, accountability as well as commitment towards further development of the EL approach will not be feasible in the SEECEL member states without dedicated support, cooperation and coordination of all key stakeholders, public, private sectors as well as, the civil society and interest groups. In order to embed the EL concept in the national policy planning of the involved countries, the effective partnership of all involved key actors appears to be one of the most relevant preconditions. In SEECEL member countries, where cooperation and coordination of all involved key actors was more intense and effective, achievements were significant and their impact more pronounced. The observations presented in questionnaires and interviews indicated that developed cooperation and coordination of all involved actors and stakeholders facilitated the reaching of consensus and effective policy implementation. Evaluation results confirmed that SEECEL's programme was the main trigger for developing such cooperation and coordination, establishing effective partnerships aiming at the exchange of best practices and mutual learning.

On the whole, our research and evaluation results indicate that SEECEL had a very relevant and far reaching role in developing and further strengthening of the EL approach in SEE member countries. SEECEL has demonstrated that its role was meaningful in supporting the most successful pilot institutions and achieved results in SEE, as well as in pushing the less successful ones, which have started with piloting at a later stage. Finally, its role is recognized in speeding up the learning process, as well as fostering meaningful cooperation and transfer of knowledge and experience between the SEE region and more developed EU member states.

\section{REFERENCES}

Baker A.C., Jensen P.J., \& Kolb D.A. (2005). Conversation as experiential learning. Management Learning, 36(4), 411-427. doi:10.1177/1350507605058130.

Bartlett, W. (2013). International Assistance Programmes and the Reform of Vocational Education in the Western Balkans: Sources of Policy Failure. Southeastern Europe, 37, 330-348. doi:10.1163/18763332-03703005.

Burgoyne, J.G., \& Hodgson, V.E. (1983). Natural learning and managerial action: A phenomenological study in the field setting. Journal of Management Studies, 20(3), 387-399. doi:10.1111/j.1467-6486.1983. tb00214.x.

Carayannis, E.G., Evans, D., \& Hanson, M. (2003). A cross-cultural learning strategy for entrepreneurship education: outline of key concepts and lessons learned from a comparative study of entrepreneurship students in France and the US. Technovation, 23(9), 757-771. doi:10.1016/S0166-4972(02)00030-5.

Cope, J. (2005). Toward a dynamic learning perspective of entrepreneurship. Entrepreneurship Theory and Practice, 29(4), 373-397. doi:10.1111/j.15406520.2005.00090.x.

Corbett, A.C. (2005). Experiential learning within the process of opportunity identification and exploitation. Entrepreneurship Theory and Practice, 29(4), 473-491. doi:10.1111/j.1540-6520.2005.00094.x.

Daudelin, M.W. (1996). Learning from experience through reflection. Organizational Dynamics, 24(3), 36-48. doi:10.1016/S0090-2616(96)90004-2.

European Commission. (2012). Effects and impact of entrepreneurship programmes in higher education. Retrieved August 6, 2015, from http://ec.europa. eu/enterprise/newsroom/cf/itemdetail.cfm?item type $=254$ \&lang=en\&item_id=5894.

Fiet, J.O. (2001). The pedagogical side of entrepreneurship theory. Journal of Business Venturing, 16(2), 101-117. doi:10.1016/S0883-9026(99)00042-7.

Gibb, A.A. (2002). In pursuit of a new 'enterprise' and 'entrepreneurship' paradigm for learning: creative destruction, new values of doing things and new combinations of knowledge. International Journal of Management Review, 4(3), 233-269. doi:10.1111/1468-2370.00086.

Gibb, A.A. (2005). Towards the Entrepreneurial University: Entrepreneurship Education as a lever for change. Retrieved August 6, 2015, from http:// irandanesh.febpco.com/FileEssay/karafarin-c1386-10-30-m21.pdf. 
Gribben, A.A. (2013). Entrepreneurial learning: Keystone to an entrepreneurial culture. INFORM, 16, 1-4.

Harrison, R.T., \& Leitch. C.M. (2005). Entrepreneurial learning: Researching the interface between learning and the entrepreneurial context. Entrepreneurship Theory and Practice, 29(4), 351-371. doi:10.1111/ j.1540-6520.2005.00089.x.

Heinonen, J., \& Poikkijoki, S.A. (2006). An entrepreneurial-directed approach to entrepreneurship education: mission impossible? Journal of Management Development, 25(1), 80-94. doi:10.1108/02621710610637981.

Holcomb, T.R., Ireland, R.D., Holmes Jr., R.M., \& Hitt, M.A. (2009). Architecture of Entrepreneurial Learning: Exploring the Link Among Heuristics, Knowledge, and Action. Entrepreneurship Theory and Practice: Special Issue on Strategic Entrepreneurship, 33(1), 173-198. doi:10.1111/j.1540-6520.2008.00285.x.

Kakkonen, M.L. (2010). Entrepreneurial Learning and Learning Strategies of the First Year Business Students in Higher Education. International Journal of Euro-Mediterranean Studies, 3(1), 85-102.

Karajić, D., Dabić, M., \& Cingula, M. (2012). Interaction among national experts for the entrepreneurial learning, within pan-European network. Procedia-Social and Behavioral Sciences, 37, 247256. doi:10.1016/j.sbspro.2012.03.291.

Kolb, D.A. (1984). Experiential learning: Experience as the source of learning and development. Englewood Cliffs, NJ: Prentice Hall.

Maleković, S., \& Tišma, S. (2011). Evaluating Pre Accession Assistance - Rethinking its Effectiveness in Promoting Developmental Change. In: 9th International Conference on Enterprise in Transition: proceedings. Split: Faculty of Economics.

McLaughlin, R., \& Thorpe, R. (1993). Action learning - a paradigm in emergence: The problems facing a challenge to traditional management education and development. British Journal of Management, 4(1), 19-27. doi:10.1111/j.1467-8551.1993.tb00158.x.

Minniti, M., \& Bygrave W. (2001). A dynamic model of entrepreneurial learning. Entrepreneurship Theory and Practice, 23(4), 41-52.

Mumford, A. (1994). A Review of Action Learning Literature. Management Bibliographies and Reviews, 20(6/7), 2-16.

Pittaway, L., Gazzard, J., Shore, A., \& Williamson, T. (2012). Entrepreneurial learning through experience: The hidden role of student clubs in management education. Center for Entrepreneurial Learning and Leadership. Retrieved August 6, 2015, from http:// eagleentrepreneur.files.wordpress.com/2012/01/ entrepreneurial_learning_through_experience_v13111.pdf.

Politis, D. (2005). The process of entrepreneurial learning: A conceptual framework. Entrepreneurship Theory and Practice, 29(4), 399-424. doi:10.1111/ j.1540-6520.2005.00091.x.

Rae, D. (2000). Understanding entrepreneurial learning: a question of how? International Journal of Entrepreneurial Behaviour \& Research, 6(3), 145-159. doi:10.1108/13552550010346497.

Rae, D., \& Carswell, M. (2001). Towards a conceptual understanding of entrepreneurial learning. Journal of Small Business and Enterprise Development, 8(2), 150-158. doi:10.1108/EUM0000000006816.

Rae, D. (2006). Entrepreneurial learning: A conceptual framework for technology-based enterprise. Technology Analysis \& Strategic Management, 18(1), 39-56. doi:10.1080 $=09537320500520494$.

Rae, D. (2009). Connecting entrepreneurial learning and action learning in student-initiated new business ventures: The case of speed. Action Learning: Research and Practice, 6(3), 289-303. doi:10.1080/14767330903301799.

Rae, D. (2011). Inspiring Entrepreneurial Learning in the New Era, The Inspiring Enterprise Conference, Glyndwr University. Retrieved August 6, 2015, from http://vimeo.com/25400146.

Raelin J.A. (1997). A model of work-based learning. Organization Science, 8(6), 563-578. doi:10.1287/ orsc.8.6.563.

Sogunro, O.A. (2004). Efficacy of role-playing pedagogy in training leaders: some reflections. Journal of Management Development, 23(4), 355-371. doi:10.1108/02621710410529802.

Tafra, V. (2011). Nacionalna strategija učenja za poduzetništvo. In: V. Tafra \& I. Tafra (Eds.), Učenje za poduzetništvo (pp. 17- 33). Zagreb. In Croatian.

Tkalec, Z. (2011). Definicija i karakteristike poduzetništva kao ključne kompetencije cjeloživotnog učenja. In: V. Tafra \& I. Tafra (Eds.), Učenje za poduzetništvo (pp. 35- 43). Zagreb. In Croatian.

Van't Rood, R., \& Maleković, S. (2012). Independent external evaluation, evaluation report of the SEECEL activities 2009-2012. Zagreb: SEECEL. 


\section{ZNAČAJ PREDUZETNIČKOG UČENJA ZA UKUPAN SOCIO-EKONOMSKI RAZVOJ NA PRIMERU CENTRA ZA PREDUZETNIČKO UČENJE JUGOISTOČNE EVROPE U HRVATSKOJ}

\section{Rezime:}

Ovaj rad bavi se pitanjem politike preduzetničkog učenja u južnoj i istočnoj Evropi, kao rezultatom aktivnosti Centra za preduzetničko učenje jugoistočne Evrope koji je osnovan u Hrvatskoj. Autori nastoje da ispitaju kako koncept preduzetničkog učenja može da doprinese i razvoju preduzetničkog načina razmišljanja i ponašanja, razvoju kreativnog mišljenja i preduzetničkog duha pojedinca bez obzira na to da li ima želju da započne privatni biznis ili ne. U radu se takođe razmatra u kojoj meri razmena iskustava, partnerstvo i saradnja svih obrazovnih i drugih institucija i pojedinaca uključenih u razvoj politike utiče na dalji razvoj preduzetničkog učenja u zemljama jugoistočne Evrope. Autori razmatraju različite perspektive i načine razumevanja i sagledavanja koncepta preduzetničkog učenja, ukazuju na postojanje različitih škola preduzetničkog učenja i ispituju odnos između učenja i preduzetništva.

\section{Ključne reči:}

obrazovanje i obuka, preduzetničko učenje, doživotno učenje. 